\title{
Life cycle stages of the amphibian chytrid Batrachochytrium dendrobatidis
}

\author{
Lee Berger ${ }^{1,2, *}$, Alex D. Hyatt ${ }^{2}$, Rick Speare $^{1}{ }^{1}$ Joyce E. Longcore $^{3}$ \\ ${ }^{1}$ Amphibian Disease Ecology Group, School of Public Health, Tropical Medicine and Rehabilitation Science, \\ James Cook University, Townsville, Queensland 4811, Australia \\ ${ }^{2}$ Australian Animal Health Laboratory, CSIRO Livestock Industries, Private Bag 24, Geelong, Victoria 3220, Australia \\ ${ }^{3}$ Department of Biological Sciences, University of Maine, Orono, Maine 04469-5722, USA
}

\begin{abstract}
An overview of the morphology and life cycle of Batrachochytrium dendrobatidis, the cause of chytridiomycosis of amphibians, is presented. We used a range of methods to examine stages of the life cycle in culture and in frog skin, and to assess ultrastructural pathology in the skin of 2 frogs. Methods included light microscopy, transmission electron microscopy with conventional methods as well as high pressure freezing and freeze substitution, and scanning electron microscopy with critical point drying as well as examination of bulk-frozen and freeze-fractured material. Although chytridiomycosis is an emerging disease, $B$. dendrobatidis has adaptations that suggest it has long been evolved to live within cells in the dynamic tissue of the stratified epidermis. Sporangia developed at a rate that coincided with the maturation of the cell, and fungal discharge tubes usually opened onto the distal surface of epidermal cells of the stratum corneum. A zone of condensed, fibrillar, host cytoplasm surrounded some sporangia. Hyperkeratosis may be due to (1) a hyperplastic response that leads to an increased turnover of epidermal cells, and (2) premature keratinization and death of infected cells.
\end{abstract}

KEY WORDS: Batrachochytrium dendrobatidis · Chytridiomycosis · Fungus • Morphology · Ultrastructure · Transmission and scanning electron microscopy $\cdot$ Pathology $\cdot$ Amphibian

\section{INTRODUCTION}

Batrachochytrium dendrobatidis causes a potentially fatal epidermal infection of amphibians and has caused mass mortality, population declines and extinctions (Berger et al. 1999, Speare et al. 2001, McDonald et al. 2005). Chytridiomycosis has been recorded from Australia, New Zealand, Europe, Africa, and South, Central and North America, from a broad range of habitats (Berger et al. 1999, Lips 1999, Mutschmann et al. 2000, Bosch et al. 2001, Fellers et al. 2001, Speare et al. 2001, Bradley et al. 2002, Weldon et al. 2004). Mortality rates of up to $100 \%$ occurred during natural outbreaks in captivity and in transmission experiments in captive amphibians of susceptible species (Berger et al. 1998, Longcore et al. 1999, Berger 2001, Nichols et al. 2001), although other species can survive infection (Ardipradja 2001, Davidson et al. 2003). Death in sus- ceptible experimental animals usually occurs from between 18 and $70 \mathrm{~d}$ post exposure and incubation time varies with dose, fungal strain, temperature and amphibian species (Ardipradja 2001, Berger 2001, Nichols et al. 2001, Woodhams et al. 2003, Berger et al. 2004). Amphibians with no clinical signs frequently carry light infections in the wild (Hopkins \& Channing 2003, Hanselmann et al. 2004, Retallick et al. 2004, McDonald et al. 2005).

The amphibian chytrid was placed in a new genus, Batrachochytrium (Phylum Chytridiomycota, Class Chytridiomycetes, Order Chytridiales) (Longcore et al. 1999). Photographs of an isolate from a captive blue poison dart frog Dendrobates azureus that died at the National Zoological Park in Washington, DC, USA, were designated as the nomenclatural type of the species, which was named $B$. dendrobatidis (Longcore et al. 1999). The ultrastructural morphology of its zoospore, 
its occurrence on an amphibian host and small subunit ribosomal DNA (ssu-rDNA) sequence of $B$. dendrobatidis indicate that this fungus is distinctly different from other known chytrids (Berger et al. 1998, Longcore et al. 1999, James et al. 2000). It is the only member of this phylum to cause disease in a vertebrate.

The life cycle of Batrachochytrium dendrobatidis is a simple progression from zoospore to the growing organism, called a thallus, which produces a single zoosporangium (= container for zoospores). The contents of the zoosporangium (also known as a sporangium) cleave into new zoospores which exit the sporangium through one or more papillae. Sexual reproduction has not been observed. Colonial development resulting from the formation of more than 1 sporangium from 1 zoospore is the only known variation of the cycle (Longcore et al. 1999). The life cycle seems to be the same in culture and in skin. The duration of the life cycle in vitro is 4 to $5 \mathrm{~d}$ at $22^{\circ} \mathrm{C}$ and is assumed to be the same in amphibian skin, although this has not been tested.

Batrachochytrium dendrobatidis discharges zoospores through an inoperculate opening and exhibits monocentric or colonial growth (Longcore et al. 1999). Longcore et al. (1999) comprehensively described the taxonomic features of $B$. dendrobatidis and gave detailed morphology based on light microscopic observations of cultures and ultrastructure of serially sectioned zoospores, but did not describe the appearance of life cycle stages using scanning electron microscopy (SEM).

Significant ultrastructural differences were not observed among zoospores of isolates from Australia, the USA or Central America (Berger et al. 1998, Longcore et al. 1999). Multilocus sequence typing (MLST) has been used to examine genetic diversity among fungal strains from North America, Panama, Australia and from frogs imported from Africa, and only 5 variable nucleotide positions were detected among 10 loci (5918 bp)(Morehouse et al. 2003). These results suggest that Batrachochytrium dendrobatidis is a recently emerged clone and support the epidemiological data showing that chytridiomycosis has been introduced into many countries from a common source. There is evidence that Africa is the origin (Weldon et al. 2004).

In amphibians sporangia infect cells in the stratum granulosum and stratum corneum in the superficial epidermis. Immature sporangia occur within the deeper, more viable cells while mature zoosporangia and empty sporangia are more prevalent in the outer keratinized layers. Discharge tubes generally project towards the skin surface and zoospores may be released to the environment. The distribution of sporangia in developing tadpoles follows the changes in the distribution of keratinized epidermis (Marantelli et al. 2004).
Resistant resting spores have not been found in histologically prepared slides of infected skin or during examination of fresh skin in the process of isolating the fungus from more than 80 amphibians (J. E. Longcore unpubl. data). MLST sequencing studies indicate that Batrachochytrium dendrobatidis reproduces clonally, which supports the lack, or uncommon occurrence, of a sexually produced resting stage (Morehouse et al. 2003).

The histopathology of chytridiomycosis based on examination of haematoxylin and eosin stained sections has been described (Berger et al. 1998, Pessier et al. 1999, Berger 2001). Infection almost always causes hyperkeratosis in the region of the thalli. Other changes include irregular multifocal hyperplasia, disordered epidermal cell layers, spongiosis, erosions and occasional ulcerations of the skin. Epidermal width is highly variable with diffuse or focal thickening in some areas, as well as large areas of thinning. Individual epidermal cell pyknosis and vacuolation may occur in scattered cells in the stratum basale or more superficial layers near infection foci. Occasionally vacuolated degenerate cells appear to coalesce into vesicles that result in lifting of the epidermis and erosion. There may be a mild inflammatory response with a slight increase in mononuclear cells in the dermis, but inflammatory response in the epidermis is uncommon.

Two hypotheses have been proposed to explain how a fungus that is restricted to the superficial epidermis has the capacity to kill frogs (Berger et al. 1998, Pessier et al. 1999). (1) The chytrid might release proteolytic enzymes or other active compounds that are absorbed through the permeable skin of the frog or, possibly, (2) damage to skin function results in disturbance of oxygen, water or electrolyte balance which results in death. By examining the ultrastructural pathology in epidermal cells we aim to improve our understanding of the effect of Batrachochytrium dendrobatidis on epidermal cells.

Cultures of Batrachochytrium dendrobatidis are highly susceptible to a range of antifungal drugs and antifungal peptides produced by frogs (Berger 2001, Rollins-Smith et al. 2002, Johnson et al. 2003). However, since topical antifungal treatment of frogs has variable efficacy, it appears that $B$. dendrobatidis is less susceptible when present in amphibian skin (Berger 2001). The reason for this is not known, but one hypothesis is that thalli are protected by their intracellular location in epidermal cells. One aim of our transmission electron microscopy (TEM) studies is to determine if the epidermal cell undergoes modifications that may explain this protection.

This study was undertaken to improve our understanding of the morphology of Batrachochytrium dendrobatidis by using TEM and SEM of all fungal stages 
in culture and in epidermis. To understand the pathogenesis of chytridiomycosis and why chytridiomycosis appears resistant to antifungal drugs we used ultrastructural studies of infected epidermis to examine the effect of the fungus on amphibian cells.

\section{MATERIALS AND METHODS}

Samples. Light microscopic studies of Batrachochytrium dendrobatidis in culture were of isolate Melbourne-Ldumerilii-98-LB-1 from a captive, ill Limnodynastes dumerilii. For ultrastructural studies we examined the isolate Tully-Ndayi-98-LB-1 from a free-living, ill Nyctimystes dayi collected from Tully, Queensland. Cultures were isolated and maintained on tryptone/gelatin hydrolysate/lactose (TGhL) agar or broth using routine methods (Longcore et al. 1999). Infected skin samples were from a wild Litoria lesueuri from Goomburra, Queensland (AAHL 97 574/1) that died and was fixed in $2.5 \%$ glutaraldehyde, a captive Bufo marinus that died and was fixed in $10 \%$ formalin, and 2 captive L. gracilenta were used for high pressure freezing. The latter samples were a toe-clip taken from a healthy infected frog with a light infection, and skin from a frog that had recently died with severe chytridiomycosis. These samples were kept on ice for about $2 \mathrm{~h}$ before processing.

TEM. Conventional processing: Samples of skin were fixed in $2.5 \%(\mathrm{v} / \mathrm{v})$ glutaraldehyde in $0.1 \mathrm{M}$ cacodylate buffer ( $\mathrm{pH} 6.8,300 \mathrm{mOsm} \mathrm{kg}^{-1}$ ) for $1 \mathrm{~h}$, washed in buffer $(3 \times 20 \mathrm{~min})$, post-fixed in $1 \%(\mathrm{w} / \mathrm{v})$ osmium tetroxide in $0.1 \mathrm{M}$ cacodylate buffer for $1 \mathrm{~h}$ followed by washing $(3 \times 5 \mathrm{~min})$ in reverse osmosis water. Samples were then dehydrated in graded alcohols (70 to $100 \%$ ), infiltrated with Spurrs resin by placing them in 50/50 Spurrs $/ 100 \%$ ethanol and then in 2 changes of $100 \%$ Spurrs followed by embedding in Spurrs epoxy resin at $65^{\circ} \mathrm{C}$ (overnight). Fixation of cultures of Batrachochytrium dendrobatidis differed in that glutaraldehyde was added to the culture medium (TGhL broth) to a final concentration of $2.5 \%$. Preliminary experiments revealed that zoospores were sensitive to the osmolality of the buffer, but TGhL broth was found to cause no discernible artifacts in the cytoplasm.

High pressure freezing and freeze substitution: Samples of Batrachochytrium dendrobatidis culture and of infected frog skin were rapidly frozen under high pressure (2000 bars) within a Leica high-pressure freezer. Brass planchets were soaked in a lecithinchloroform solution and allowed to dry before packing with agar cultures or pieces of toe skin. A range of embedding media was used: TGhL broth, $2.3 \mathrm{M}$ sucrose, hexadecene and hexene. The frozen plan- chets were stored in liquid nitrogen until processing. Substitution was initiated by placing planchets and samples within perforated beam capsules in $1 \%(\mathrm{w} / \mathrm{v})$ osmium tetroxide/2.5\% (v/v) glutaraldehyde in 100\% acetone at $-90^{\circ} \mathrm{C}$ in the presence of a molecular sieve within a 'Leica CS auto' for $8 \mathrm{~d}$. The temperature was raised to $-60^{\circ} \mathrm{C}$ at $2.5^{\circ} \mathrm{C} \mathrm{h}^{-1}$ and kept at $-60^{\circ} \mathrm{C}$ for $2 \mathrm{~d}$. The temperature was then raised to $-18^{\circ} \mathrm{C}$ at $2.5^{\circ} \mathrm{C} \mathrm{h}^{-1}$ then up to $0^{\circ} \mathrm{C}$ at $10^{\circ} \mathrm{C} \mathrm{h}^{-1}$ and the media replaced with $100 \%$ acetone. Samples were then warmed to room temperature $\left(24^{\circ} \mathrm{C}\right)$ in $1 \mathrm{~h}$. The substitution medium was replaced with 1:1 propylene oxide (PO):acetone, $100 \%$ PO, 1:1 PO:epon, $100 \%$ epon $\times 2$ and embedded at $60^{\circ} \mathrm{C}$ for $24 \mathrm{~h}$. All media used in planchets resulted in excellent preservation of samples.

Cutting and examination of samples: Thick sections were examined with methylene blue stain by light microscopy to identify and select the sections containing sporangia. Ultra-thin sections $(70 \mathrm{~nm})$ were cut on a Leica-Reichert-Jung Ultracut E microtome, floated and adhered onto a grid, double stained in uranyl acetate and lead citrate and examined with a Hitachi H7000 or Philips CM 120 transmission electron microscope at 75 or $100 \mathrm{kV}$.

SEM. Critical point drying: Skin was fixed in phosphate buffered $2.5 \%$ glutaraldehyde for $1 \mathrm{~h}$, washed in phosphate buffer (pH 6.8, $300 \mathrm{~m} \mathrm{Osm} \mathrm{kg}^{-1}$ ) for $15 \mathrm{~min}$, post-fixed in buffered $1 \%(\mathrm{w} / \mathrm{v})$ osmium tetroxide for $3 \mathrm{~h}$, and rinsed in the same buffer $(\times 10)$. Samples were then placed in saturated aqueous filtered thiocarbohydrazide $(1 \% \mathrm{w} / \mathrm{v})$ for $10 \mathrm{~min}$, rinsed in distilled water $(\times 10)$, then placed in $1 \%(\mathrm{w} / \mathrm{v})$ aqueous osmium tetroxide at $0^{\circ} \mathrm{C}(30 \mathrm{~min})$, rinsed in reverse osmosis water and sequentially dehydrated in graded alcohol (70 to $100 \%$ ). Following dehydration, tissues were critically point dried from liquid carbon dioxide, mounted on a stub with carbon dag, and sputter coated with gold. Samples were viewed with a JEOL JSM 840 scanning electron microscope at 5 to $15 \mathrm{kV}$ with a working distance of between 16 and $22 \mathrm{~mm}$.

Bulk-frozen hydrated samples (agar): Cultures were examined with a JEOL 6340F field emission scanning electron microscope fitted with an Oxford 1500 cryo system. Blocks of $5 \mathrm{~d}$ old agar cultures were adhered to stubs with OCT compound cryo adhesive (Tissue Tek) and then plunged into melting nitrogen and transferred under vacuum to the microscope at liquid nitrogen temperature. Samples were etched at $-95^{\circ} \mathrm{C}$ for $60 \mathrm{~s}$, then coated with gold/palladium in the transfer chamber. Samples were examined at $2 \mathrm{kV}$ and a working distance of $20 \mathrm{~mm}$.

Bulk-frozen hydrated samples (coverslip): To obtain a cleaner view of the base of sporangia, cultures were grown on sterile, round, plastic, $13 \mathrm{~mm}$ coverslips (Thermanox), by placing coverslips in petri dishes of 
active TGhL broth culture. Between 6 and $10 \mathrm{~d}$, broth was removed by rinsing the coverslips through 3 changes of distilled water. Excess water was removed by touching the edges with filter paper, and leaving them to dry for about $1 \mathrm{~min}$. To reduce charging, coverslips were cut into quarters before they were adhered to the stub with carbon dag. Stubs were plunged into melting nitrogen then transferred under vacuum at liquid nitrogen temperature to the Hexland chamber and into the JEOL JSM-840 at $-170^{\circ} \mathrm{C}$. Extended drying at $-80^{\circ} \mathrm{C}$ was necessary to sublimate ice, and good results were obtained on a sample that was desiccated overnight and examined as a freeze-dried sample; however, an effect of freeze drying is shrinkage. Some sporangia did not withstand this form of dehydration and shrank, presenting a crumpled appearance. Samples were gold-coated within the antechamber of the microscope. Samples were examined at 3 to $5 \mathrm{kV}$ and a working distance of $20 \mathrm{~mm}$.

Freeze fracture: Freeze fracture preparations were produced and examined using a Philips XL30 FEG or
JEOL JSM-840 SEM. Six to $14 \mathrm{~d}$ old agar cultures were packed into rivets that were joined upright. After plunging in melting nitrogen and placing in the transfer chamber of the microscope, the top rivet was knocked off, exposing the fractured surface of the culture. The sample was etched at $-96^{\circ} \mathrm{C}$ for 2 min to remove about $1200 \mathrm{~nm}$ water, and coated with platinum or gold. The sample was etched again at $-100^{\circ} \mathrm{C}$ for 2 min. Samples were examined at $6 \mathrm{kV}$ with a working distance of $20 \mathrm{~mm}$.

\section{RESULTS AND REVIEW OF MORPHOLOGY}

\section{Zoospore}

Zoospores are the unwalled, waterborne, motile, flagellated stage (Figs. 1 to 4). Zoospores of Batrachochytrium dendrobatidis are mostly spherical but can be elongate and amoeboid when first released from the zoosporangium (Longcore et al. 1999). They
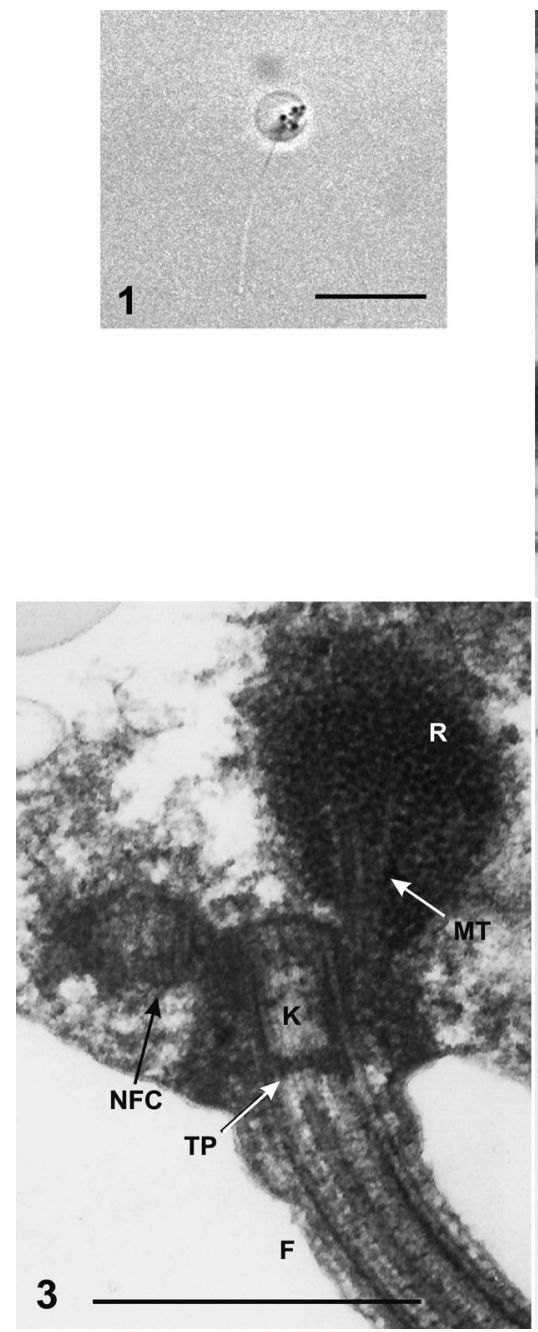
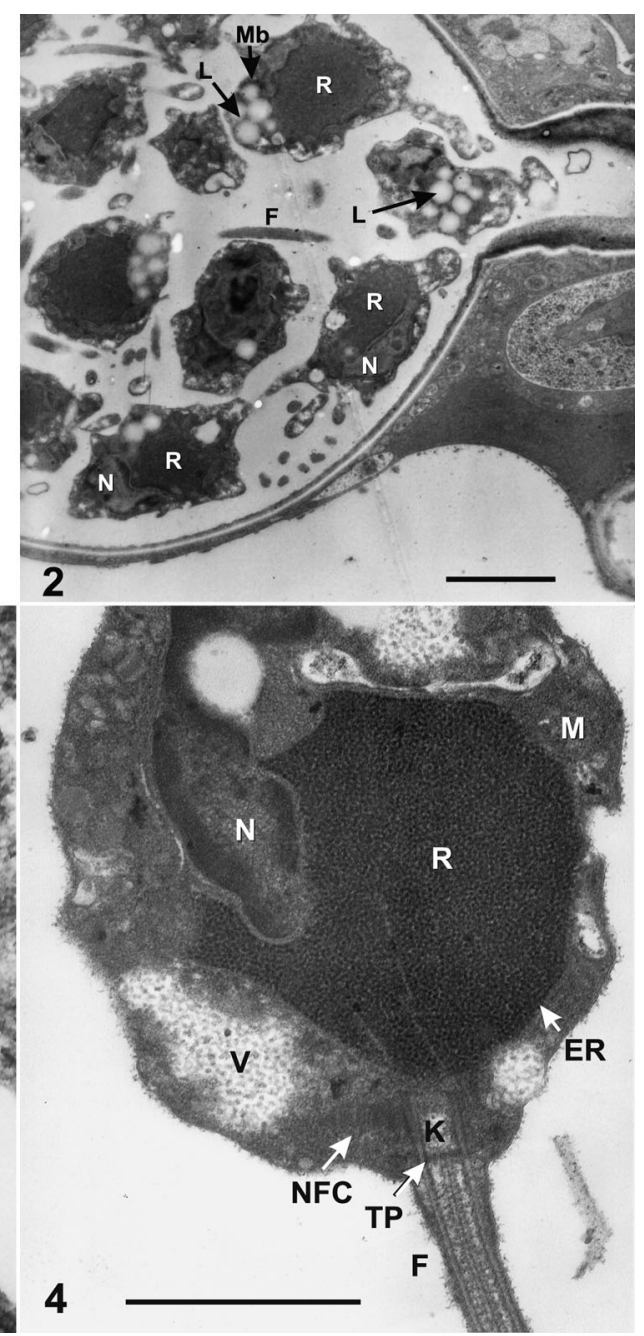

Figs. 1 to 4 . Batrachochytrium dendrobatidis. Fig. 1. Light micrograph of live cultured zoospore. Dark droplets are probably lipid globules. Scale bar $=$ $6 \mu \mathrm{m}$. Figs. 2 to 4 . B. dendrobatidis. Transmission electron micrographs of zoospores. Fig. 2. Formalin-fixed zoospores within a zoosporangium in the skin of Bufo marinus. Zoospores are being released and contain numerous lipid globules that are partially surrounded by the microbody and occur at the edge of the ribosomal mass. Scale bar $=2 \mu \mathrm{m}$. Fig. 3. Glutaraldehyde-fixed cultured zoospore. The nonflagellate centriole (NFC) is parallel to the kinetosome. Microtubule root runs parallel to the kinetosome and is embedded in a cone of ribosomes. Scale bar $=0.6 \mu \mathrm{m}$. Fig. 4 . Glutaraldehyde-fixed cultured zoospore. Nucleus is not associated with the kinetosome and is nested in the ribosomal mass which is surrounded by endoplasmic reticulum. Mitochondria are adjacent to the ribosomal mass. Scale bar $=1 \mu \mathrm{m} . \mathrm{F}=$ flagellum; $\mathrm{N}=$ nucleus; $\mathrm{R}=$ ribosomes; $\mathrm{Mb}=$ microbody; $\mathrm{L}=$ lipid droplet; $\mathrm{K}=$ kinetosome; $\mathrm{M}=$ mitochondria; $\mathrm{Tp}=$ terminal plate $; \mathrm{V}=$ vacuole $; \mathrm{ER}=$ endoplasmic reticulum; $\mathrm{MT}=$ microtubules 
are about 3-5 $\mathrm{mm}$ in diameter with a posteriorly directed flagellum (19-20 $\mu \mathrm{m}$ in length) (Longcore et al. 1999). After a period of motility and dispersal, the zoospore encysts. The flagellum is resorbed and a cell wall forms (Fig. 5).

Zoospore ultrastructure is used to differentiate orders and genera and many important taxonomic features are in the flagellar apparatus. The ultrastructure of the flagellar region is best explained by diagrams (see Fuller 1996). The features of the zoospore of Batrachochytrium dendrobatidis that are common to the order Chytridiales are that the nucleus and kinetosome are not associated, ribosomes are aggregated into a core surrounded by endoplasmic reticulum, the microbody partially surrounds the lipid globules, and the nonflagellated centriole (NFC) is parallel and connected to the kinetosome (Longcore 1993, Longcore et al. 1999). A key feature of $B$. dendrobatidis is the numerous small lipid droplets with the microbodies that are associated with the edge of the ribosomal mass (Longcore et al. 1999) (Fig. 2). The kinetosomal root is comprised of a group of microtubules that run parallel to the kinetosome as they extend into the ribosomal mass (Fig. 3). Additional key taxonomic structures not shown here are that the microtubule root arises near triplets 9-1 of the kinetosome, and that overlapping fibers connect the NFC with the kinetosome. The nucleus is partially nested in the ribosomal mass, mitochondria are adjacent to the ribosomal mass and zoospores contain a single Golgi apparatus (Fig. 4). Most members of the Chytridiales have a rumposome abutting the edge of a single lipid globule and many have a transition zone plug, but these are not present in B. dendrobatidis (Berger et al. 1998, Longcore et al. 1999).

\section{Germling}

After the zoospore has encysted, fine branching rhizoids grow from one or more areas and the young sporangium is known as a germling (Fig. 6). In pure cultures, occasional germlings grew on adjacent sporangia (Fig. 7).
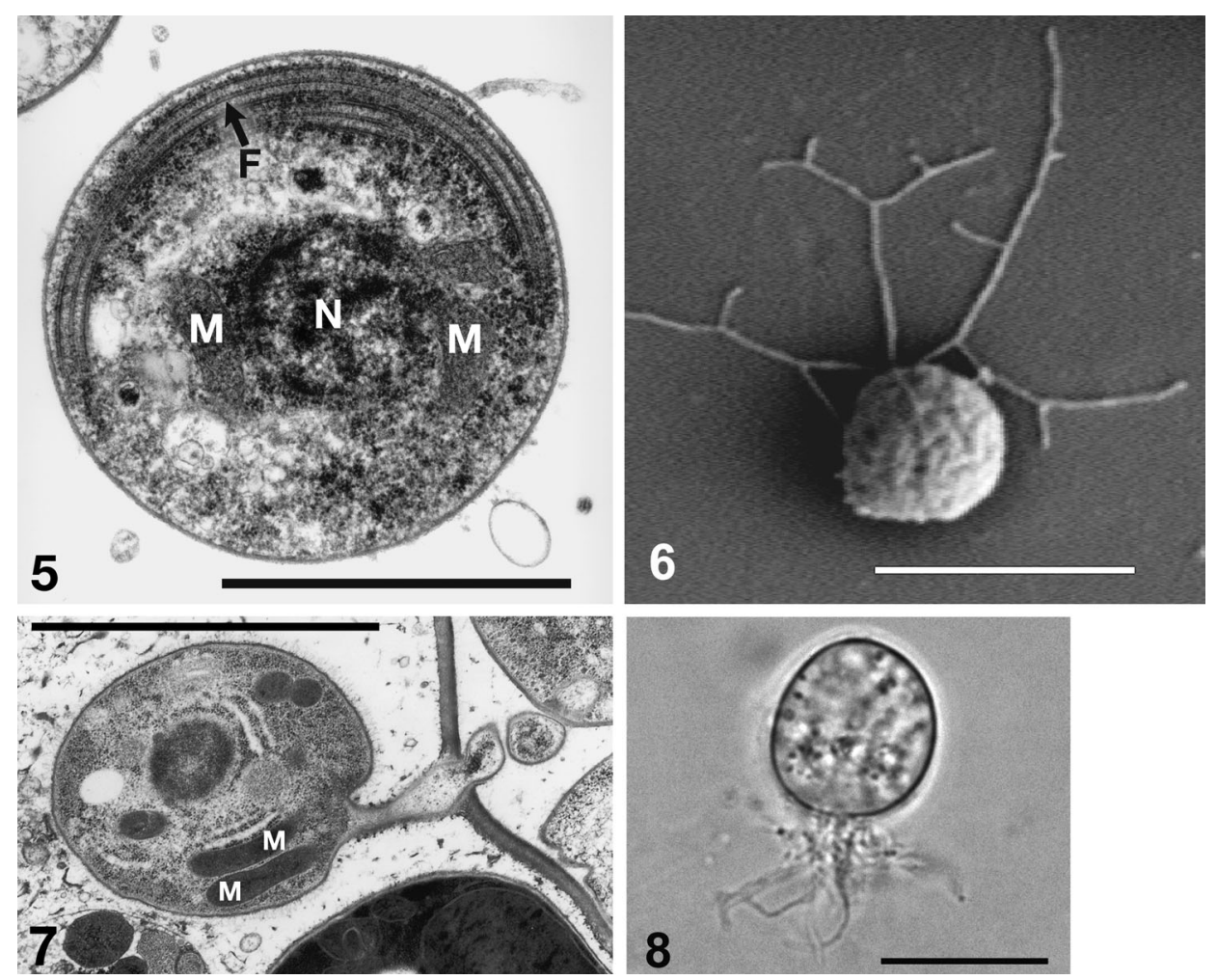

Figs. 5 to 8. Batrachochytrium dendrobatidis. Fig. 5. Glutaraldehyde-fixed encysted zoospore. The resorbed flagellum is visible and a cell wall has formed. Ribosomes are distributed throughout the cytoplasm. Scale bar $=2 \mu$ m. Fig. 6 . Scanning electron micrograph (SEM) of a germling showing fine rhizoids spreading out along the substrate. The culture was grown on a plastic coverslip and prepared by freeze-drying. The crumpled surface is an artifact of freeze-drying. Scale bar $=10 \mu \mathrm{m}$. Fig. 7 . Transmission electron micrograph (TEM) of a young sporangium growing on an adjacent sporangium. Prepared by high pressure freezing and freeze substitution (HPF/FS). Scale bar $=10 \mu \mathrm{m}$. Fig. 8. Live immature sporangium with rhizoids spreading out. Scale bar $=10 \mu \mathrm{m}$. $\mathrm{F}$ = flagellum, $\mathrm{N}=$ nucleus, $\mathrm{M}=$ mitochondria 


\section{Developing zoosporangia}

As the thalli grow, the cytoplasm becomes more complex (Figs. 8 to 18) and becomes multinucleate by mitotic divisions. The entire contents then cleave and mature into rounded, flagellated zoospores. The swollen part of the thallus is now known as a zoosporangium. During sporangial development, one or more discharge papillae form. Some young thalli become divided by thin septa and each compartment grows into a separate sporangium with its own discharge tube; this mode of development is referred to as 'colonial growth'. A thallus that forms a single sporangium has no divisions and the type of development is termed 'monocentric' (Longcore et al. 1999). Mature zoosporangia contain fully formed flagellated zoospores (Fig. 2). Actively motile zoospores were observed within sporangia before they exited. After the plug blocking the discharge tube dissolves, zoospores are released. The length of discharge tubes is variable even within an isolate, from virtually nothing up to
$10 \mu \mathrm{m}$, and depends on type of media and density of culture. Longer tubes were seen in skin and agar cultures than in broth. Mature zoosporangia of many chytrids do not discharge if the environment is too dry for zoospore release; in amphibian tissue zoosporangia of Batrachochytrium dendrobatidis may also retain their zoospores until sufficient moisture is present to induce zoospore discharge, but in culture on $1 \%$ agar medium, sufficient moisture is present that zoospores discharge without additional liquid.

\section{Empty sporangia}

After zoospores have been released, sporangia are clear, indicating that they are empty (Fig. 19). The chitinous walls of the sporangia remain and may collapse. Occasional zoospores do not escape and grow within sporangia (Fig. 20). In frog skin bacteria may enter through the open discharge tubes and replicate inside (Figs. 20, $29 \& 30$ ).

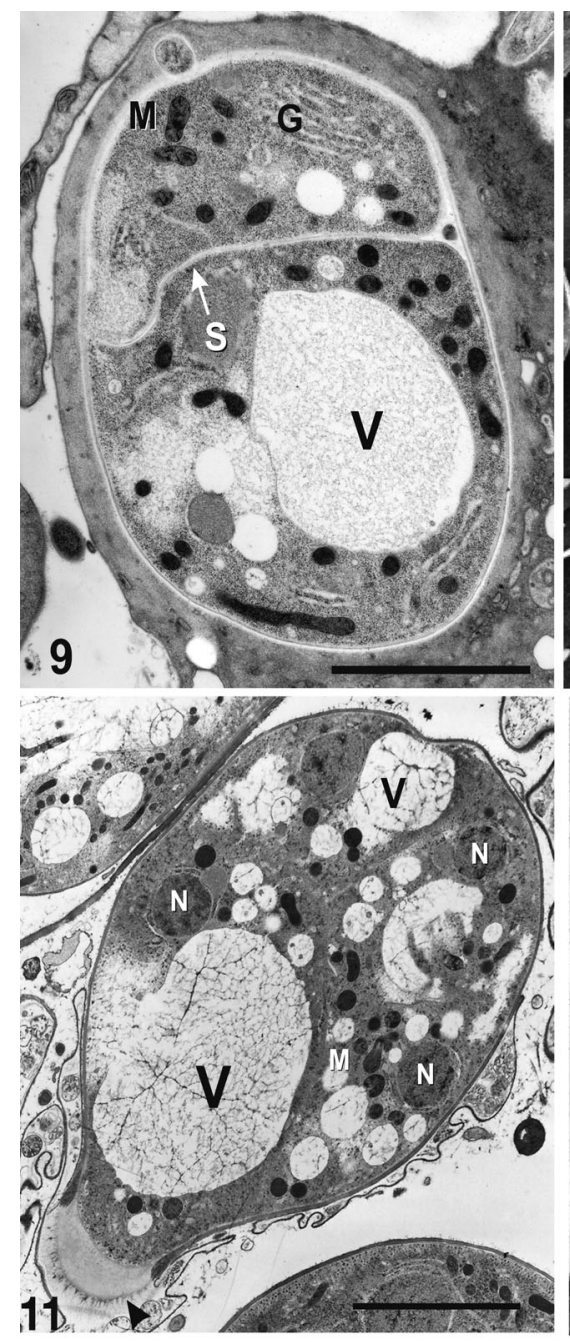

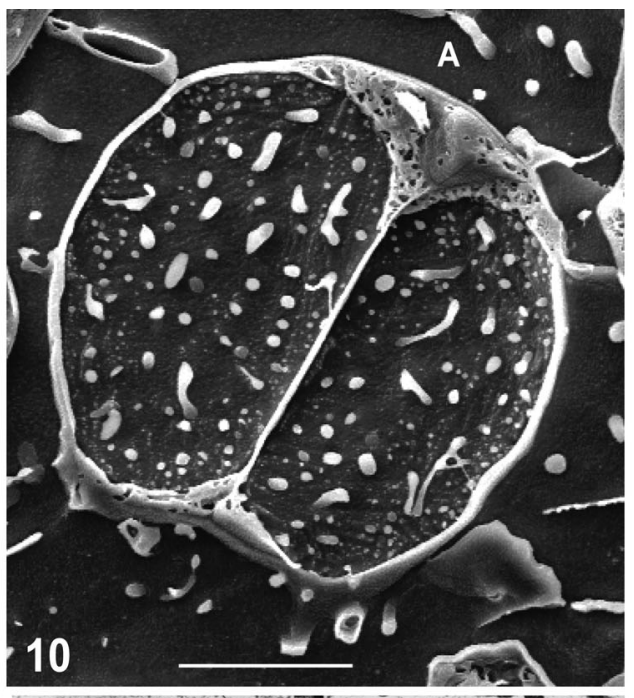

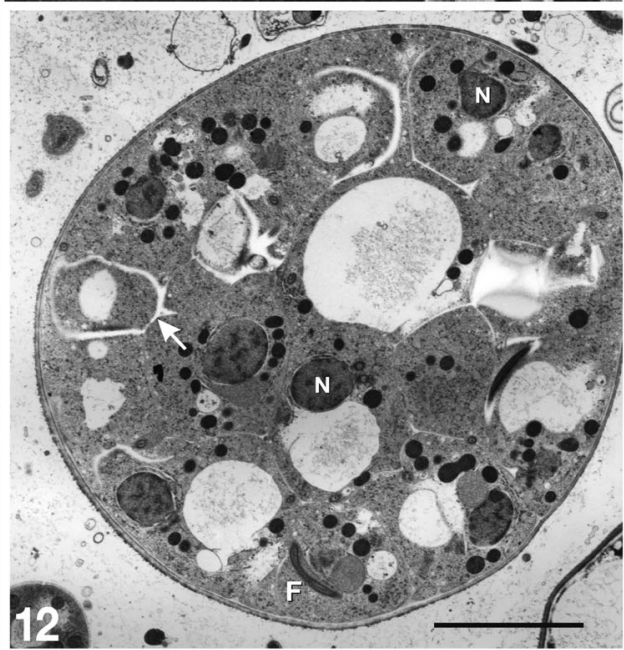

Figs. 9 to 12. Batrachochytrium dendrobatidis. Fig. 9. TEM (HPF/ FS) of an immature colonial sporangium in skin of a Litoria gracilenta. A septum (S) divides the thallus into 2 compartments. Scale bar $=5 \mu \mathrm{m}$. Fig. 10. SEM of bulk-frozen hydrated culture that has been freeze-fractured. The image shows a colonial thallus divided by a septum. Scale bar $=5 \mu \mathrm{m}$. Fig. 11. TEM (HPF/FS) of an immature sporangium with a discharge papilla. The cell is multinucleate after mitotic divisions, but the cytoplasm has not yet divided. Plug blocking the discharge papilla is clearly seen (arrowhead). The wall over the tip of the plug has dissolved, demonstrating that $B$. dendrobatidis is inoperculate. Early stages often have large vacuoles (V). Transverse sections of rhizoids occur in spaces between sporangia. Scale bar = $5 \mu \mathrm{m}$. Fig. 12. TEM (HPF/FS) of a multinucleate sporangium that is beginning to cleave into zoospores. Arrow indicates a cleavage line. Scale bar $=4 \mu \mathrm{m} . \mathrm{G}=$ golgi, $\mathrm{M}=$ mitochondria, $\mathrm{A}=$ agar, $\mathrm{N}=$ nucleus, $\mathrm{F}=$ flagellum 


\section{Colonies in culture}

On agar, cultures of Batrachochytrium dendrobatidis grow as granular, cream-colored clusters (Fig. 21). The zoospores swarm in a film of surface liquid surrounding each colony. They encyst at the base of the colony and push the older sporangia upwards. Thalli grow better in clusters and isolated zoospores placed on agar usually die. This 'group effect' (Longcore et al. 1999) is unusual in chytrids, and may indicate that the nutrient medium is not optimal. Rhizoids spread over the surface of adjacent sporangia and tightly intermingle with rhizoids from other sporangia, joining them together (Figs. 22 to 25). Zoospores appear to be attracted to colonies.

\section{Batrachochytrium dendrobatidis in skin}

The same stages of the life cycle occur within epidermal cells of amphibian skin as in culture, although it has not been determined whether thalli in skin differ in their rate of development (Figs. 26 to 28). Up to 3 sporangia were seen within a single epidermal cell. Immature stages occur in the deeper viable cells. Mature zoosporangia and empty stages occur in the sloughing stratum corneum. By the time most sporangia have completed their development, they have been carried to the skin surface with the differentiating epidermal cells. Discharge tubes usually point towards the skin surface, whereas in culture they may grow laterally as well as upwards. Discharge tubes usually protrude to the surface through a hole in the epidermal cell membrane. The cell membrane of the keratinized skin cell adheres closely to the surface of the discharge tube. The edge of the cell membrane was not easily discerned by SEM but was obvious by TEM in crosssection (Figs. $28 \& 29$ ). Some zoosporangia mature while still covered by cornified cell layers that have not been sloughed, and appear to discharge zoospores into the intercellular spaces.

Colonial development can occur in skin and sporangia with internal septa can be seen in histological sections, although most thalli in skin are not colonial. Bacteria on the skin multiply on the layers of shedding keratin and commonly grow in empty sporangia (Figs. 29 \& 30). Sporangia in the skin are smaller than in culture, where they are up to $40 \mu \mathrm{m}$ in diameter (Longcore et al. 1999), suggesting that being intracellular restricts their growth. Rhizoids were rarely seen in skin sections examined by electron microscopy. They could not be seen in haematoxylin and eosin stained histology sections, but were discernible adjacent to sporangia when stained with the immunoperoxidase stain (Berger et al. 2002). The fungi are often found in clusters on skin,

Figs. 13 to 16. Batrachochytrium dendrobatidis. Fig. 13. TEM (HPF/FS) of a sporangium in skin of a Litoria gracilenta with a cytoplasm that has divided into incompletely formed flagellated zoospores. Scale bar $=5 \mu \mathrm{m}$. Fig. 14. SEM of a bulk-frozen hydrated sporangium that has been freeze-fractured. Image is a 3-dimensional representation of the similar staged sporangium in Fig. 13. Scale bar $=5 \mu \mathrm{m}$. Fig. 15. Live sporangia with discharge papillae. Internal structures of the sporangia are at various stages of zoospore development. Scale bar $=20 \mu \mathrm{m}$. Fig. 16. SEM of a large zoosporangium on agar with 5 papillae visible. Zoospores are congregating and encysting around the base. Prepared by bulk-freezing hydrated culture. Scale bar $=10 \mu \mathrm{m}$. $\mathrm{N}=$ nucleus, $\mathrm{M}=$ mitochondria, $\mathrm{F}=$ flagellum, $\mathrm{V}=$ vacuole, $\mathrm{A}=$ agar 

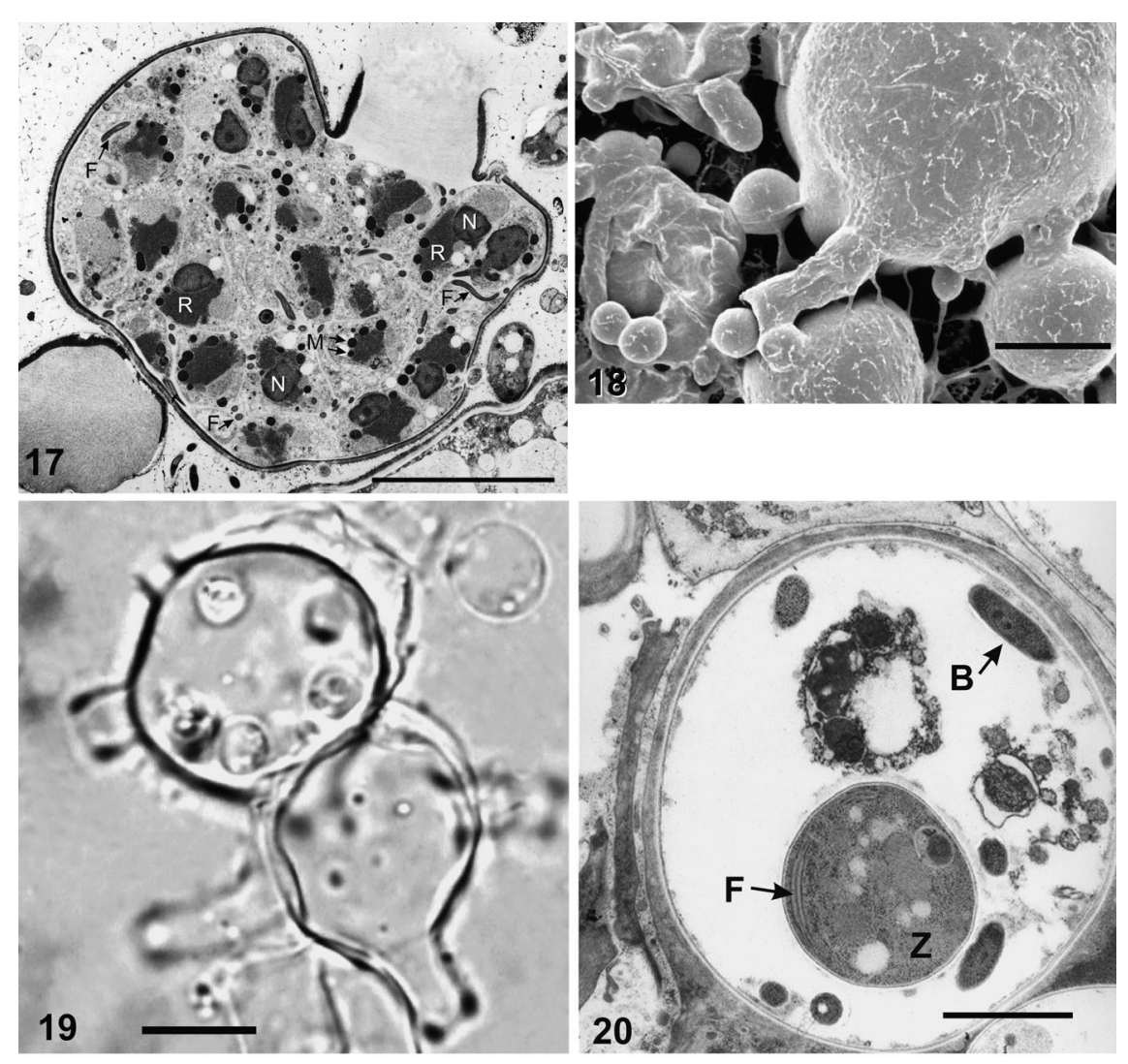

Figs. 17 to 20. Batrachochytrium dendrobatidis. Fig. 17. TEM (HPF/ FS) of a mature zoosporangium with discharge papilla and plug. It is packed with flagellated zoospores; reprinted from Berger et al. (1999). Scale bar = $10 \mu \mathrm{m}$. Fig. 18. SEM of a zoosporangium on agar with an encysted zoospore at the end of a long discharge tube. Prepared by bulkfreezing hydrated culture. Reprinted from Boyle et al. (2003). Scale bar = $10 \mu \mathrm{m}$. Fig. 19. Sporangia that have released most of their zoospores. Scale bar $=10 \mu \mathrm{m}$. Fig. 20. TEM (HPF/FS) of an old sporangium in the keratinized skin of a Litoria gracilenta. A zoospore ( $\mathrm{Z}$ ) that was not released has encysted inside; note thickened wall and resorbed flagellum $(\mathrm{F})$. A degenerate zoospore and bacteria (B) are also inside. Scale bar $=2 \mu \mathrm{m}$. $\mathrm{M}=$ mitochondria, $\mathrm{R}=$ ribosomal mass, $\mathrm{N}=$ nucleus
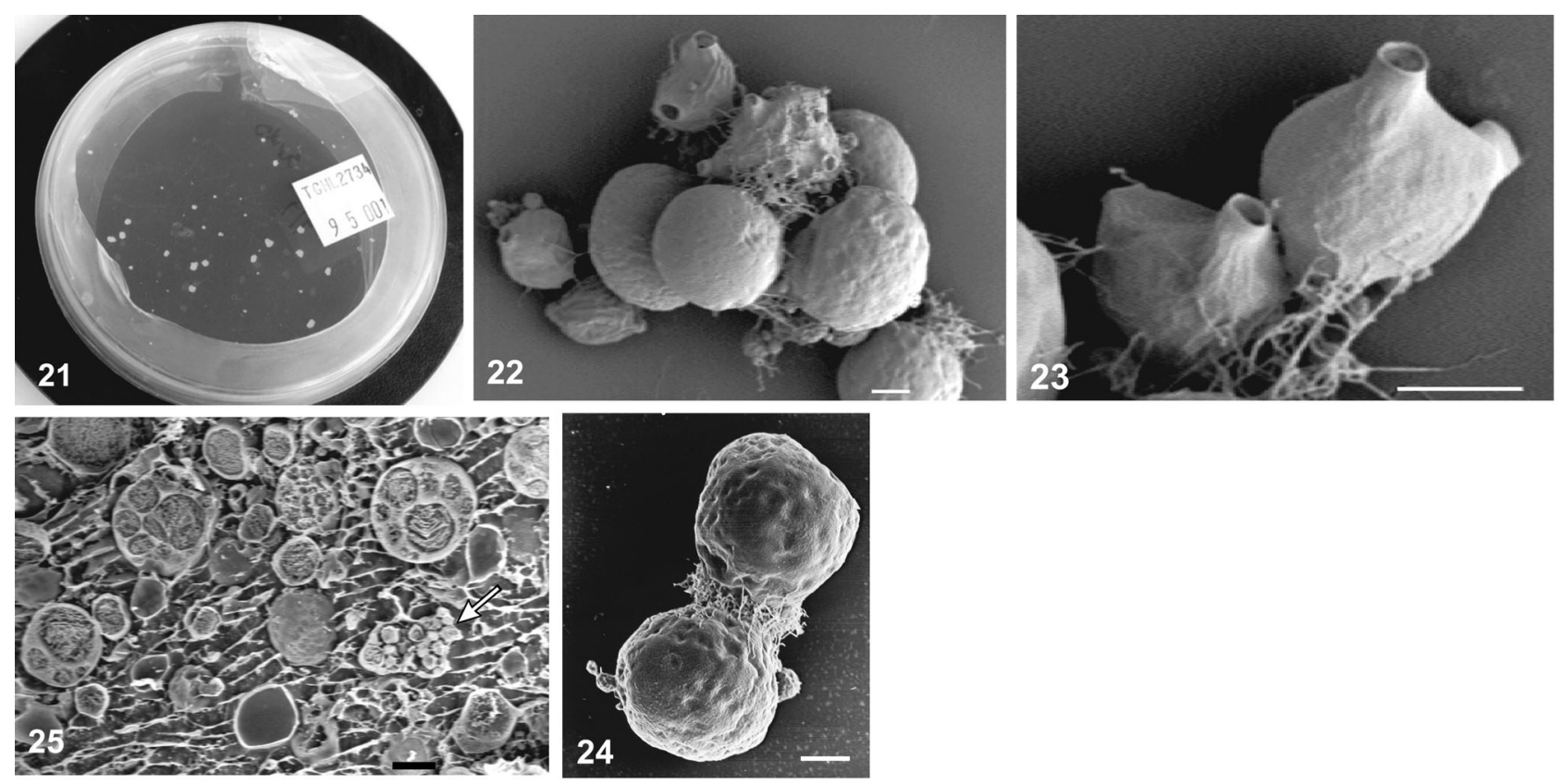

Figs. 21 to 25. Batrachochytrium dendrobatidis. Fig. 21. Culture on TGhL agar plate. Colonies appear as granular, creamcoloured mounds. Fig. 22. SEM of a cluster of sporangia grown on a plastic coverslip and freeze-dried. Some sporangia have 2 or more open discharge tubes. Threadlike rhizoids hold sporangia together. Scale bar $=10 \mu \mathrm{m}$. Fig. 23. SEM of thalli with 2 discharge tubes demonstrating the aptness of the name 'chytrid' (i.e. earthen pot in Greek). Rhizoids from adjacent sporangia are growing over the surface. Culture was grown on a plastic coverslip and freeze-dried. Scale bar $=10 \mu \mathrm{m}$. Fig. 24 . SEM of $2 \mathrm{spo-}$ rangia showing the attraction between their rhizoids. Culture was grown on a plastic coverslip and freeze-dried. Scale bar $=$ $10 \mu \mathrm{m}$. Fig. 25. SEM of freeze-fractured preparation of a bulk-frozen hydrated culture in agar. Most sporangia are immature. One sporangium contains mature zoospores (arrow). Scale bar $=10 \mu \mathrm{m}$ 


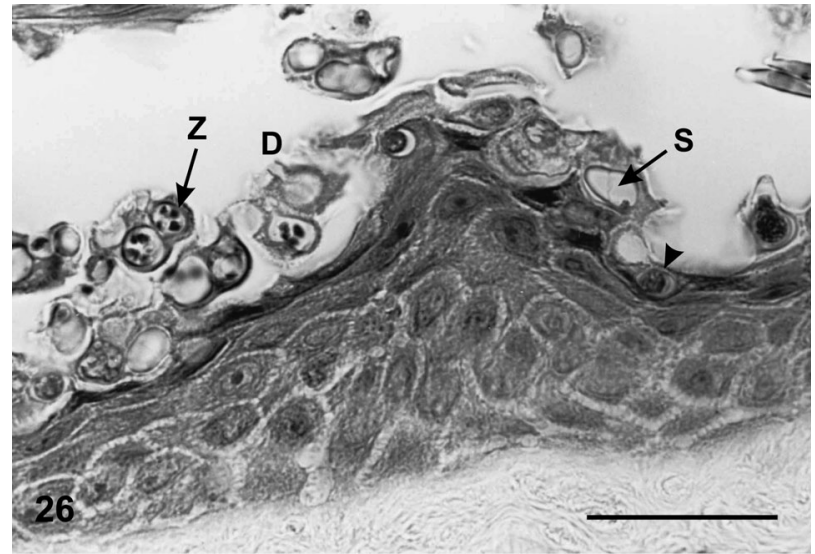

Fig. 26. Batrachochytrium dendrobatidis infecting Litoria caerulea. Histological section of skin from a L. caerulea. Dark immature fungal stages occur in the deeper cells (arrowhead). Mature zoosporangia with distinct dark zoospores (Z) and old empty stages with open discharge tubes (D) occur in the sloughing stratum corneum. Note the colonial thallus with an internal septum (S). Haematoxylin and eosin stain. Scale bar $=30 \mu \mathrm{m}$

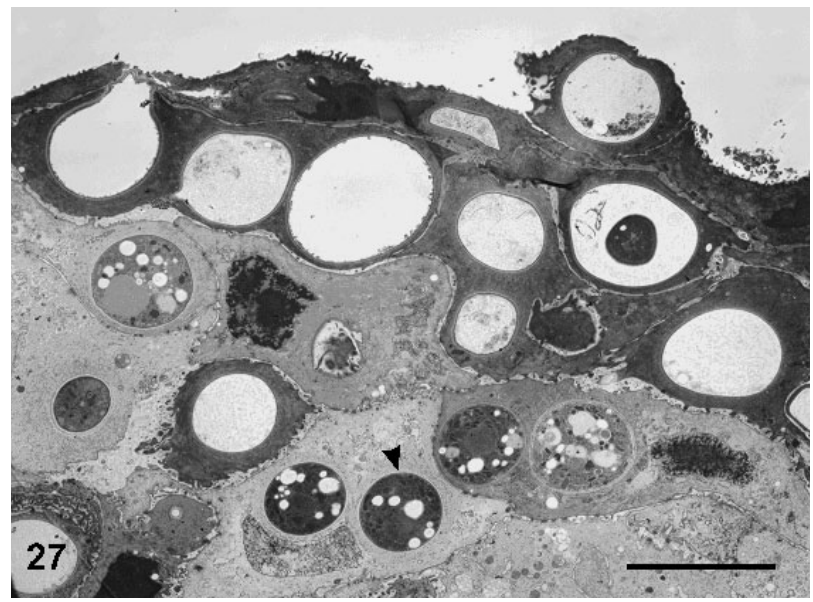

Fig. 27. Batrachochytrium dendrobatidis infecting Litoria gracilenta. TEM (HPF/FS) of skin from a L. gracilenta with immature, solid stages deeper in the epidermis (arrowhead), and old empty stages in the flattened, dark, keratinized cells. Infected cells contain between 1 and 3 sporangia. Scale bar $=10 \mu \mathrm{m}$

Figs. 28 to 30. Batrachochytrium dendrobatidis. Fig. 28. SEM of infected toe skin of a Litoria lesueuri. Almost all epidermal cells in this field are infected and are bulging. Closed discharge tubes protrude through the skin surface (arrow). Prepared by critical point drying. Scale bar $=10 \mu \mathrm{m}$. Fig. 29. TEM (HPF/FS) of skin of a Litoria gracilenta showing an old sporangium containing bacteria (B) and a zoospore (Z). Discharge tube is opening to the skin surface through a hole in the condensed keratinised epidermal cell. Edge of the skin tapers around the tube. Scale bar $=5 \mu \mathrm{m}$. Fig. 30. TEM (HPF/FS) of old sporangia in skin of a L gracilenta. Bacteria (B) have entered the sporangium through an open discharge tube and replicated into an ordered colony. $\mathrm{S}=$ septum in an empty colonial sporangium. Scale bar $=10 \mu \mathrm{m}$
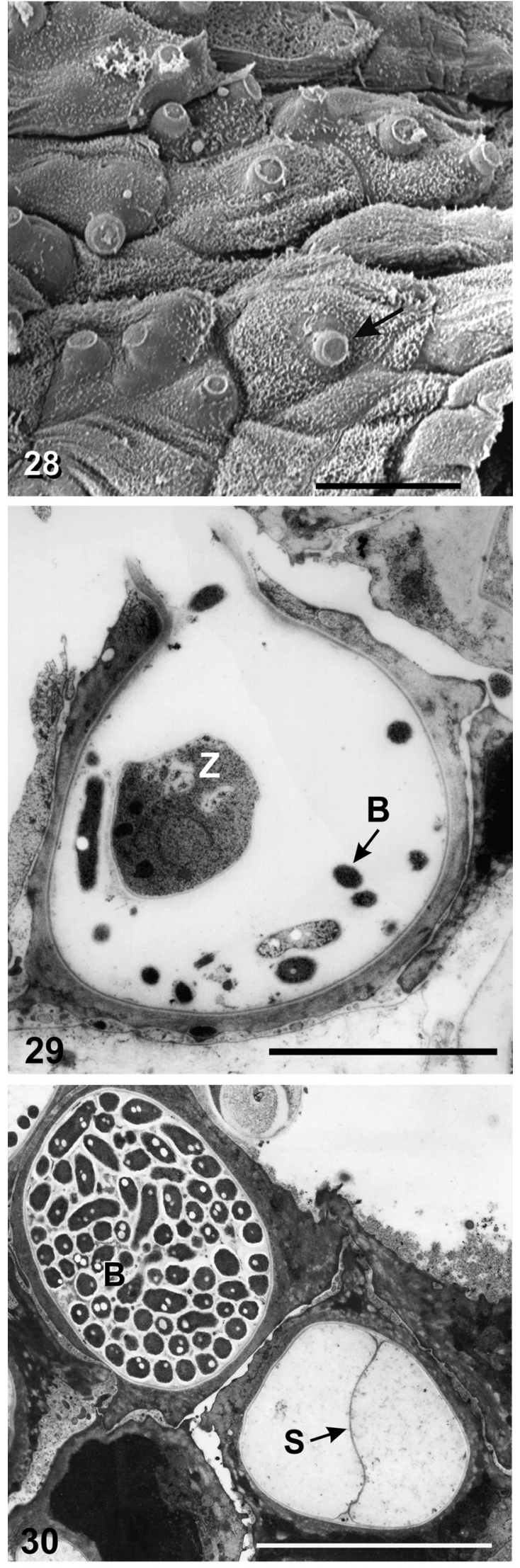
except in heavy infections where all ventral skin may be diffusely infected.

\section{Ultrastructural pathology in epidermis}

TEM of skin from the lightly infected Litoria gracilenta showed that a build up in the layers of infected keratinized cells caused the stratum corneum to become focally thickened in areas of infected epidermis. Up to 4 additional layers of infected, keratinized cells comprised the stratum corneum. These keratinized cells were darker than the keratinized cells in non-infected areas (Fig. 31).

A zone of apparently condensed host cytoplasm, up to $2.5 \mu \mathrm{m}$ thick, surrounded some sporangia. This zone appeared to be mainly fibrils with no organelles (Fig. 32). The more superficial epidermal cells contained larger sporangia and the cell nuclei and organelles such as mitochondria were located on one side of the host cell. Near the skin surface the epidermal cell cytoplasm condensed to a thin layer around the fungal thalli and host organelles were lost, in a process similar to normal epidermal cell maturation. Cell nuclei became dark and condensed but were not as flattened as in normal stratum corneum. Keratinization appeared to occur prematurely in infected cells below the skin surface, compared with uninfected cells in the same epidermal layer (Fig. 31). The cell junctions of infected cells usually appeared normal (Fig. 32).

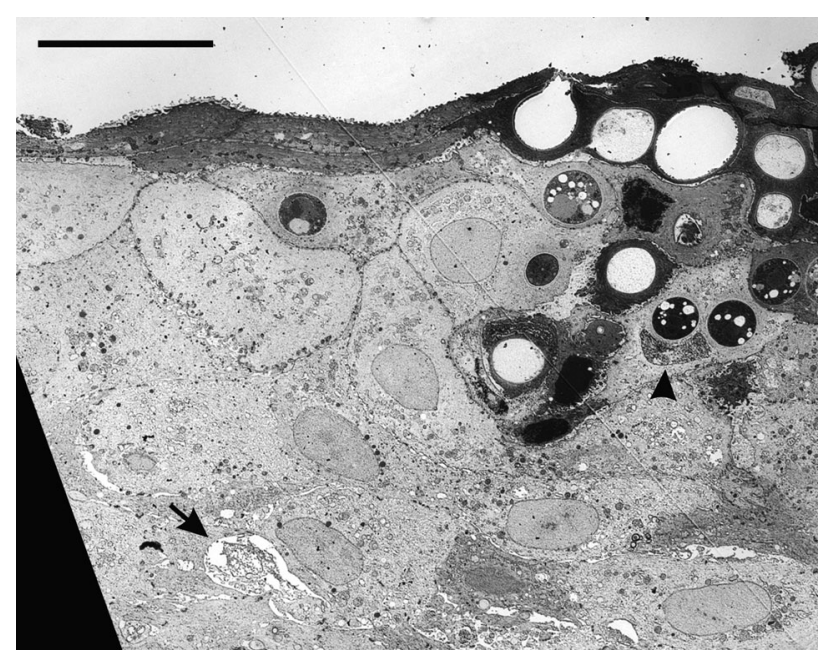

Fig. 31. Batrachochytrium dendrobatidis infecting Litoria gracilenta. TEM (HPF/FS) of infected epidermis in a L. gracilenta adult without clinical signs. There are multiple layers of dark infected keratinized cells, whereas away from the cluster of sporangia the stratum corneum is 1 cell thick. Some nuclei of infected cells are degenerate and chromatolytic (arrowhead), and necrosis and dissolution of cells is shown in the deeper epidermis (arrow). Scale bar $=18 \mu \mathrm{m}$

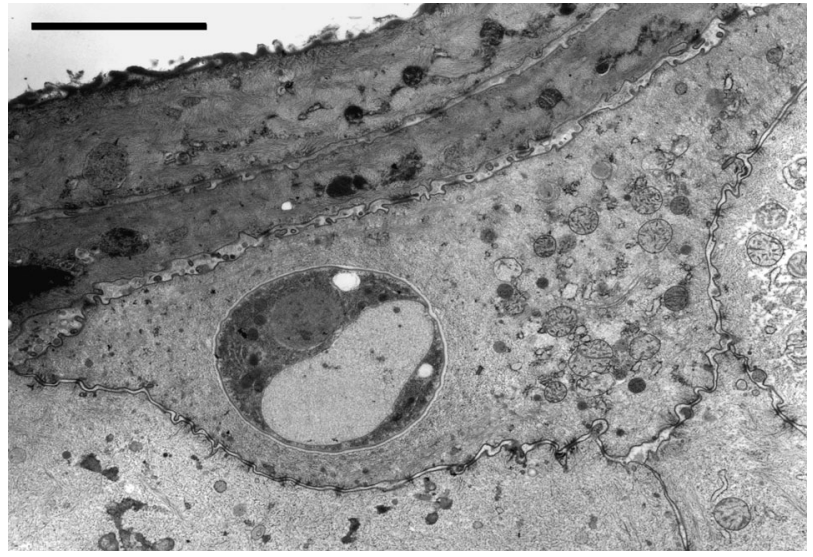

Fig. 32. Batrachochytrium dendrobatidis. Higher magnification of an infected cell from Fig. 31. A zone that contains no organelles surrounds the sporangium. Mitochondria and apparently normal cell junctions are present. Scale bar $=4 \mu \mathrm{m}$

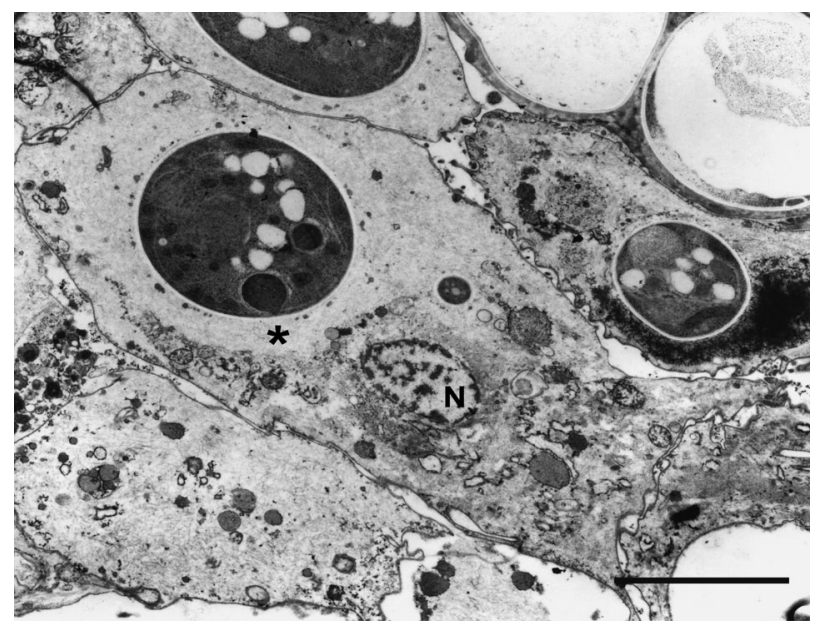

Fig. 33. Batrachochytrium dendrobatidis infecting Litoria gracilenta. TEM (HPF/FS) of superficial epidermal cells from an adult of Litoria gracilenta that died from chytridiomycosis. A clear fibrillar zone of cytoplasm surrounds the sporangium (*) and the chromatolytic nucleus (N) and necrotic organelles have been displaced. Scale bar $=6 \mu \mathrm{m}$

Infected cells and uninfected cells near foci of infection were acutely swollen, although mitochondria and other organelles in these cells were intact. Nuclei of some infected cells in the stratum granulosum were shrunken and chromatolytic. Pathology in the deeper epidermal cells, as distant as the basal layer, included focal shrinkage, increased intercellular spaces, vacuolation and dissolution of the cytoplasm (Fig. 31). Large, distinctly bordered vesicles containing sparse cytoplasmic debris occurred within some cells.

The Litoria gracilenta that died from chytridiomycosis had severe epidermal lesions (Fig. 33). Although some intracellular changes could be attributed to 
autolysis, major structural changes were evident. Maturation of epidermal cells was disrupted, and shedding cells were often pale and incompletely keratinized with overly plump nuclei. In eroded areas cells sloughed to expose a non-keratinized surface. Many epidermal cells were severely necrotic with swollen, degenerate nuclei and mitochondria. Some necrotic infected cells appeared to lack intercellular junctions, and bacteria were common between cells and within discharged sporangia.

SEM revealed that surface of skin from a healthy control frog was smooth and intact with a regular pattern demarcating adjacent cells (Fig. 34), whereas skin from the infected Litoria lesueuri exhibited roughening due to separation of adjacent cells, irregular rounding of their flat surface layers, and desquamation (Fig. 35).

\section{DISCUSSION}

The life cycle of Batrachochytrium dendrobatidis has 2 main stages: the motile, waterborne, short-lived zoospore for dispersal, and the stationary, monocentric thallus, which develops into a zoosporangium for asexual amplification (Fig. 36). B. dendrobatidis is well adapted to living in the dynamic tissue of the stratified epidermis. Sporangia live inside epidermal cells, initially parasitizing cells a few layers deep, and have a rate of development that coincides with the maturing of the cell as it moves outwards and keratinizes. They grow initially in living cells but complete their development in dead superficial keratinized cells that lack organelles. Discharge tubes have the ability to merge with and dissolve the epidermal cell membrane and open on to the surface of the cell, usually the surface distal from the body. These specialized adaptations suggest that $B$. dendrobatidis has long evolved to live in skin.

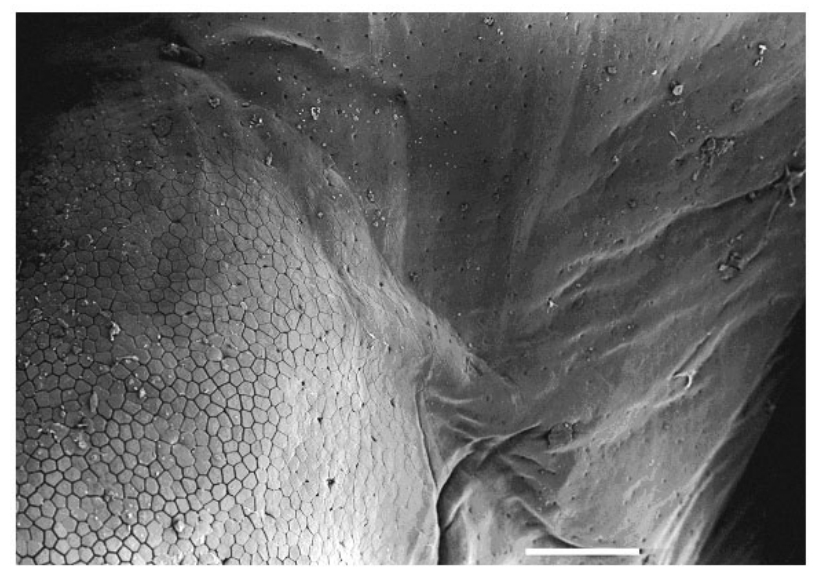

Fig. 34. Litoria caerulea. SEM of smooth intact healthy skin. Toe pad is in the left part of the image. Scale bar $=100 \mu \mathrm{m}$

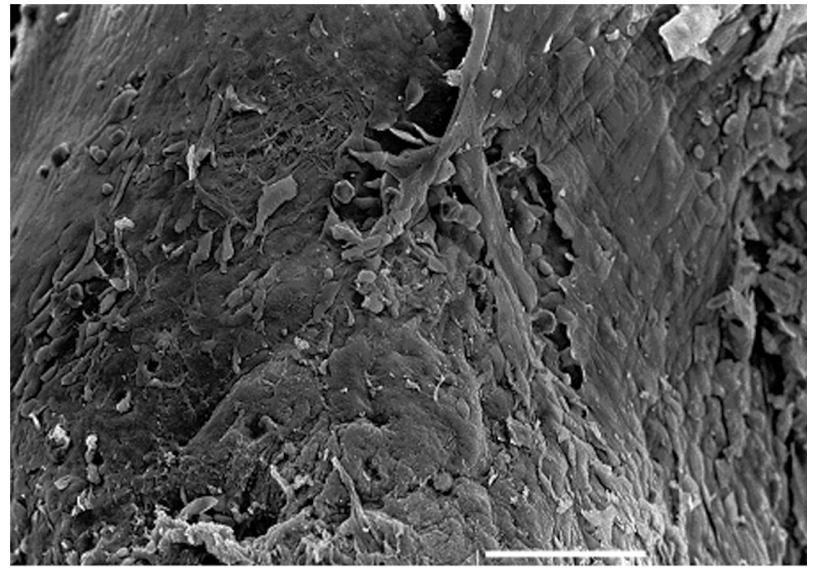

Fig. 35. Batrachochytrium dendrobatidis infecting Litoria lesueuri. SEM of the surface of skin from the foot of an infected adult of $L$. lesueuri showing the extensive degeneration and peeling of the superficial epidermis; reprinted from Berger et al. (1999). Scale bar $=100 \mu \mathrm{m}$

The distribution of sporangia in adults and tadpoles shows that a stratified, keratinizing epidermis is a requirement of Batrachochytrium dendrobatidis when occurring as a parasite (Berger et al. 1998, Marantelli et al. 2004). However, immature sporangia grow within the deeper cells that contain prekeratin, not

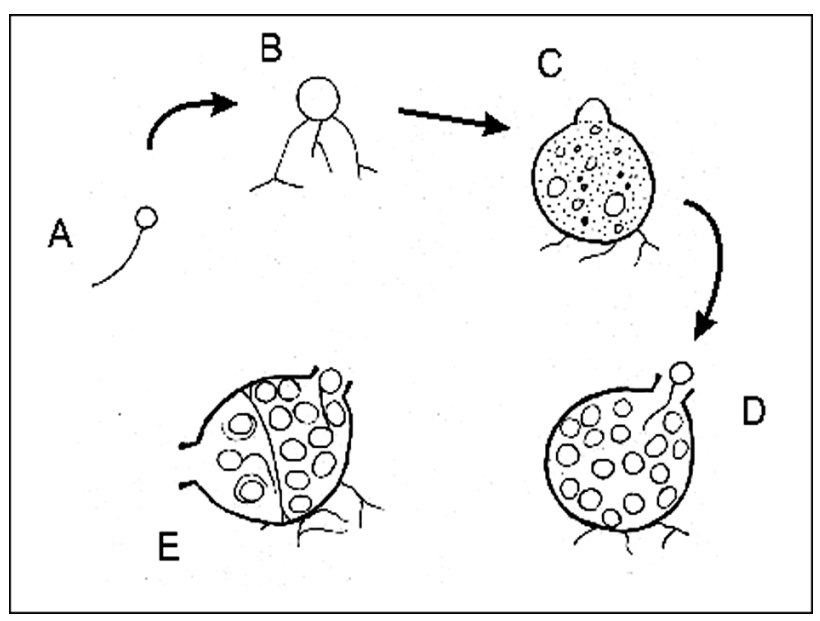

Fig. 36. Batrachochytrium dendrobatidis. Diagram of the life cycle in culture. After a period of motility (usually $<24 \mathrm{~h}$ ), zoospores encyst, resorb their flagella and form germlings. Rhizoids appear from one or more areas. The thalli grow larger and become mature sporangia over 4 to $5 \mathrm{~d}$. Contents of the enlarged thallus become multinucleate by mitotic divisions and the entire contents cleave into zoospores while the discharge tubes form. The discharge tube is closed by a plug that absorbs water and deliquesces when zoospores are ready to release. Some thalli develop colonially with thin septa dividing the contents into multiple sporangia each with their own discharge tube. $\mathrm{A}=$ zoospore, $\mathrm{B}=$ germling, $\mathrm{C}=$ developing zoosporangium, $\mathrm{D}=$ monocentric zoosporangium, $\mathrm{E}=$ colonial thallus 
the dense keratin of the outer, cornified layer where mature zoosporangia are found. Keratin has not been studied in detail in amphibians, but in mammals it is formed when the inner surface of the plasma membrane thickens and material including microfilaments, keratohyaline and lysed material are deposited into an amorphous-filamentous complex (Fox 1994). As cells mature, different keratins are expressed. It is not yet known what nutrients are being utilized by sporangia in frog skin, or if it is the structure and rate of development of stratified epidermis that make it suitable for $B$. dendrobatidis compared with other epidermal types.

Because higher temperatures (i.e. $>25^{\circ} \mathrm{C}$ ) increase the rate of epidermal turnover and reduce growth of the amphibian chytrid (Piotrowski et al. 2004), the loss of infection in frogs in warm conditions (Berger et al. 2004, McDonald et al. 2005) may occur because the fungus does not have time to complete its life cyle before being shed with the epidermal layer.

We did not see a zoospore in the act of infecting skin, so the method of penetration remains unknown. Longcore et al. (1999) suggest the zoospore could encyst on the surface then inject the nucleus and contents through a germ tube. Other chytrids have the ability to change from endobiotic to epibiotic growth depending on nutrients and the substrate (Longcore 1995). The details of the ultrastructural changes that occur within sporangia during development also remain to be studied. Experimental infection with zoospores and a time series of fixations are needed to trace the infection process.

Rhizoids were seen less commonly in skin sections than in culture, suggesting they do not grow as profusely in skin. Rhizoids may not be needed in skin as they are not required for attachment and enzymatically digested nutrients may be absorbed through the sporangial wall. Serial sectioning could be used to follow the path of rhizoids in skin.

The clustering of sporangia of Batrachochytrium dendrobatidis in the skin may occur because zoospores are attracted to foci of infection, or because zoospores that are released from a sporangium immediately infect adjacent skin with only a limited period of motility and dispersal. Some zoospores appear to be released into intercellular spaces and may not be able to escape from the site of infection.

The optimum methods for preparing germlings, developing sporangia and zoosporangia for TEM were high pressure freezing and freeze substitution. For SEM the best results were obtained by imaging bulk frozen hydrated samples via a field emission scanning electron microscope. These protocols minimize preparation artifacts such as shrinkage, which was apparent in the critical point dried samples.
Batrachochytrium dendrobatidis causes complex changes at the cellular level with 2 process being seen; (1) the ultrastructure of infected cells appears to undergo an active process of reorganization in the early stages of infection and (2) dissolution of cells occur. Examination of ultrastructural pathology revealed that hyperkeratosis appeared to be partly due to an increased turnover of epidermal cells, and the swelling of epidermal cells near foci of infection suggested a hyperplastic response. Stimulation of the stratum basale leading to hyperplasia is a common response to epidermal injury and occurs with other epidermal infections such Sarcoptes scabiei (Skerratt et al. 1999). The layers of skin in infected frogs were uneven and maturation of epidermal cells appeared disrupted. The cycle of cleavage and sloughing of keratinized cells was also disrupted with multiple layers of keratinized cells building up before being shed. Effects on infected cells included altered fibrils in the cytoplasm and displacement of the nucleus by sporangia. These changes in the ultrastructure may lead to reduced penetration of antifungal drugs into the cell. Sporangia appeared to initiate premature death and keratinization of host cells. Thinning of the epidermis may occur when the germination of epidermal cells does not match the increased rate of sloughing from the surface. Epidermal width is the result of the balance between these 2 effects and is highly variable.

We did not determine whether death is caused by toxin release or by inhibition of skin functions, but the dissolution of cellular cytoplasm that is visible (by both histological and TEM methods) in epidermal cells distant to foci of infection suggests toxicity. Overgrowth of bacteria may contribute to the pathogenesis in terminal stages. The mechanism by which Batrachochytrium dendrobatidis causes death remains one of the most important aspects yet to be understood about this pathogen. Studies on enzymes produced by $B$. dendrobatidis, effects of unpurified fungal secretions on the health of frogs, and more detailed studies on pathology and clinical pathology of infected frogs may provide answers.

Acknowledgements. We are grateful to N. Cheville for assistance with interpretation of pathology. We thank A. Marshall, Latrobe University, the Centre of Electron Microscopy and Microanalysis of South Australia at the University of Adelaide, and the Electron Microscopy Facility at the University of Melbourne for assistance in using their electron microscopy facilities. We thank G. Marantelli, H. Hines, K. McDonald and H. Parkes for providing frog specimens, and S. Hengstberger, T. Wise, and F. Filippi for help with photography. The work was supported by Environment Australia, the Australian Research Council, the Department of Environment and Heritage and NSF Integrated Research Challenges in Environmental Biology grant IBN 9977063. 


\section{LITERATURE CITED}

Ardipradja K (2001) A study of resistance towards the emerging pathogen Batrachochytrium dendrobatidis in 4 species of Australian frogs. BSc, University of Melbourne, Melbourne

Berger L (2001) Diseases in Australian frogs. PhD thesis, James Cook University, Townsville

Berger L, Speare R, Daszak P, Green DE and 10 others (1998) Chytridiomycosis causes amphibian mortality associated with population declines in the rain forests of Australia and Central America. Proc Natl Acad Sci USA 95: 9031-9036

Berger L, Speare R, Hyatt A (1999) Chytrid fungi and amphibian declines: overview, implications and future directions. In: Campbell A (ed) Declines and disappearances of Australian frogs. Environment Australia, Canberra, p 23-33

Berger L, Hyatt AD, Olsen V, Hengstberger SG, Boyle D, Marantelli G, Humphreys K, Longcore JE (2002) Production of polyclonal antibodies to Batrachochytrium dendrobatidis and their use in an immunoperoxidase test for chytridiomycosis in amphibians. Dis Aquat Org 48:213-220

Berger L, Speare R, Hines H, Marantelli G and 10 others (2004) Effect of season and temperature on mortality in amphibians due to chytridiomycosis. Aust Vet J 82:31-6

Bosch J, Martínez-Solano I, García-París M (2001) Evidence of a chytrid fungus infection involved in the decline of the common midwife toad (Alytes obstetricans) in protected areas of central Spain. Biol Conserv 97:331-337

Boyle DG, Hyatt AD, Daszak P, Berger L, Longcore JE, Porter D, Hengstberger SG, Olsen V (2003) Cryo-archiving of Batrachochytrium dendrobatidis and other chytridiomycetes. Dis Aquat Org 56:59-64

Bradley GA, Rosen PC, Sredl MJ, Jones TR, Longcore JE (2002) Chytridiomycosis in native Arizona frogs. J Wildl Dis 38:206-212

Davidson EW, Parris M, Collins JP, Longcore JE, Pessier AP, Brunner J (2003) Pathogenicity and transmission of chytridiomycosis in tiger salamanders (Ambystoma tigrinum). Copeia 2003:601-607

Fellers GM, Green DE, Longcore JE (2001) Oral chytridiomycosis in the mountain yellow-legged frog (Rana muscosa). Copeia 2001:945-953

Fox H (1994) The structure of the integument. In: Heatwole HG, Barthalmus T (eds) Amphibian biology, Vol 1. The integument. Surrey Beatty and Sons, Chipping Norton, p 1-32

Fuller MS (1996) The flagellated fungal spore. In: Sutton B (ed) A century of mycology. Cambridge University Press, Cambridge, p 161-192

Hanselmann R, Rodríguez A, Lampo M, Fajardo-Ramos L and 4 others (2004) Presence of an emerging pathogen of amphibians in introduced bullfrogs Rana catesbeiana in Venezuela. Biol Conserv 120:115-119

Hopkins S, Channing A (2003) Chytrid fungus in northern and western cape frog populations, South Africa. Herp Rev 34:334-336

James TY, Porter D, Leander CA, Vilaglys R, Longcore JE (2000) Molecular phylogenetics of the Chytridiomycota supports the utility of ultrastructural data in chytrid systematics. Can J Bot 78:336-350

Johnson M, Berger L, Philips L, Speare R (2003) Fungicidal effects of chemical disinfectants, UV light, desiccation and heat on the amphibian chytrid, Batrachochytrium dendrobatidis. Dis Aquat Org 57:255-260

Editorial responsibility: Peernel Zwart, Utrecht, The Netherlands
Lips KR (1999) Mass mortality and population declines of anurans at an upland site in western Panama. Conserv Biol 13:117-125

Longcore JE (1993) Morphology and zoospore ultrastructure of Lacustromyces hiemalis gen. et sp. nov. (Chytridiales). Can J Bot 71:414-425

Longcore JE (1995) Morphology and zoospore ultrastructure of Entophlyctis luteolus sp. nov. (Chytridiales): implications for chytrid taxonomy. Mycologia 87:25-33

Longcore JE, Pessier AP, Nichols DK (1999) Batrachochytrium dendrobatidis gen. et sp. nov., a chytrid pathogenic to amphibians. Mycologia 91:219-227

Marantelli G, Berger L, Speare R, Keegan L (2004) Distribution of Batrachochytrium dendrobatidis and keratin during tadpole development. Pac Conserv Biol 10:173-179

McDonald KR, Méndez D, Müller R, Freeman AB, Speare R (2005) Decline in the prevalence of chytridiomycosis in upland frog populations in North Queensland, Australia. Pac Conserv Biol 11:114-120

Morehouse EA, James TY, Ganley ARD, Vilgaly R, Berger L, Murphy PJ, Longcore JE (2003) Multilocus sequence typing suggests the chytrid pathogen of amphibians is a recently emerged clone. Mol Ecol 12:395-403

Mutschmann F, Berger L, Zwart P, Gaedicke C (2000) Chytridiomycosis on amphibians - first report from Europe. Berl Münch Tierärzt Wochenschr 113:380-383

Nichols DK, Lamirande EW, Pessier AP, Longcore JE (2001) Experimental transmission of cutaneous chytridiomycosis in dendrobatid frogs. J Wildl Dis 37:1-11

Pessier AP, Nichols DK, Longcore JE, Fuller MS (1999) Cutaneous chytridiomycosis in poison dart frogs (Dendrobates spp.) and White's tree frogs (Litoria caerulea). J Vet Diagn Invest 11:194-199

Piotrowski JS, Annis SL, Longcore JE (2004) Physiology of Batrachochytrium dendrobatidis, a chytrid pathogen of amphibians. Mycologia 96:9-15

Retallick RW, McCallum H, Speare R (2004) Endemic infection of the amphibian chytrid fungus in a frog community post-decline. PLoS Biol 2:e351(doi: 10.1371/journal. pbio.0020351)

Rollins-Smith LA, Carey C, Longcore J, Doersam JK, Boutte A, Bruzgal JE, Conlon J M (2002) Activity of antimicrobial skin peptides from ranid frogs against Batrachochytrium dendrobatidis, the chytrid fungus associated with global amphibian declines. Dev Comp Immunol 26:471-479

Skerratt LF, Middleton D, Beveridge I (1999) Distribution of life cycle stages of Sarcoptes scabiei var wombati and effects of severe mange on common wombats in Victoria. J Wildl Dis 35:633-646

Speare R, Alford R, Aplin R, Berger L and 11 others (2001) Nomination for listing of amphibian chytridiomycosis as a key threatening process under the Environment Protection and Biodiversity Conservation Act 1999. In: Speare R, Alford R, Aplin R, Berger L and 10 others (eds) Developing management strategies to control amphibian diseases: decreasing the risks due to communicable diseases. School of Public Health and Tropical Medicine, James Cook University, Townsville, p 186-208

Weldon C, du Preez LH, Hyatt AD, Muller R, Speare R (2004) Origin of the amphibian chytrid fungus. Emerg Infect Dis 10:2100-2105

Woodhams DC, Alford RA, Marantelli G (2003) Emerging disease cured by elevated body temperature. Dis Aquat Org 55:65-67

Submitted: March 27, 2005; Accepted: June 22, 2005

Proofs received from author(s): November 25, 2005 